\title{
CYP7A1 Gene
}

National Cancer Institute

\section{Source}

National Cancer Institute. CYP7A1 Gene. NCI Thesaurus. Code C40052.

This gene is involved in bile acid synthesis and steroid metabolism. 